\title{
Road rage behaviour and experiences of rickshaw drivers in Rawalpindi, Pakistan
}

M.A. Shaikh, ${ }^{\text {I.A. Shaikh }}{ }^{2}$ and Z. Siddiqui ${ }^{3}$

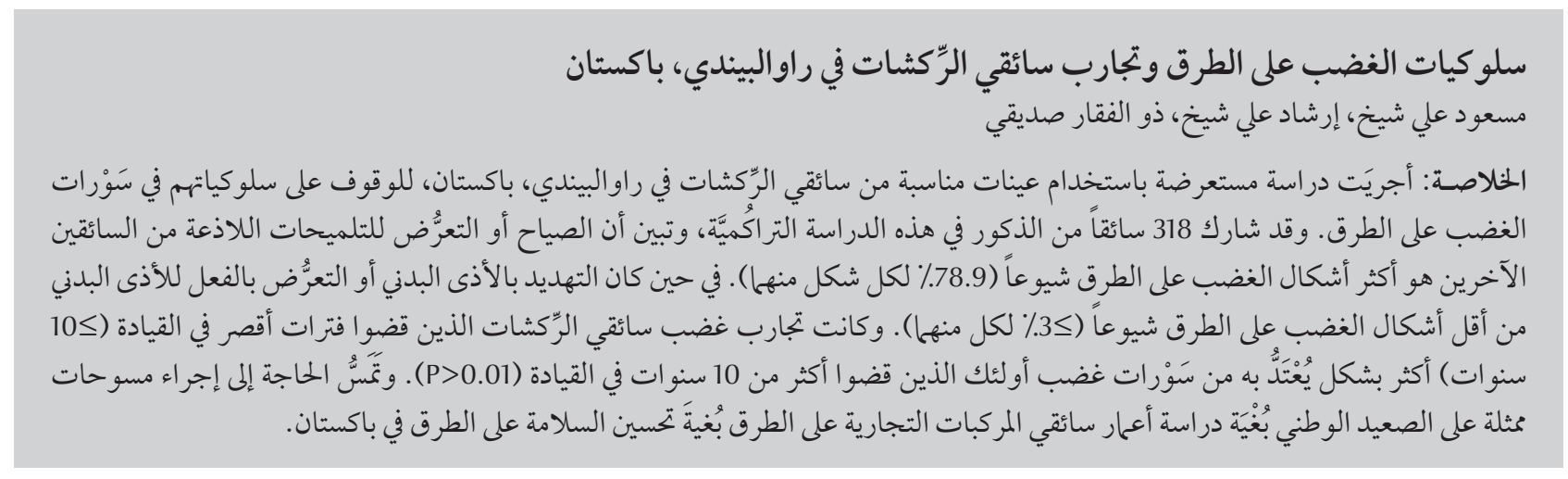

ABSTRACT A cross-sectional survey with convenience sampling was conducted among rickshaw drivers in Rawalpindi, Pakistan to study their road rage behaviour and experiences. Cumulatively 318 male drivers participated in this study. The most common forms of road rage reported were: having been shouted at; and having experienced rude gestures from other drivers (78.9\% each). Least common forms of road rage reported were: threats of physical hurt or having actually been physically hurt ( $\leq 3 \%$ each). Rickshaw drivers with shorter driving time ( $\leq 10$ years) had significantly more road rage experiences than those who had been driving for more than 10 years $(P<0.01)$. There is a need for nationally representative surveys to study road age in commercial vehicle drivers so as to improve road safety in Pakistan.

\section{Comportements et expériences de rage routière chez les conducteurs de rickshaw à Rawalpindi (Pakistan)}

RÉSUMÉ Une étude transversale a été conduite sur un échantillon de commodité incluant des conducteurs de rickshaw à Rawalpindi (Pakistan) pour évaluer leurs comportements et expériences de rage routière. Au total, 318 conducteurs de sexe masculin ont participé à l'enquête. Les expériences les plus fréquemment rapportées de rage routière (78,9\% pour chacune d'entre elles) étaient les agressions verbales et les gestes insultants de la part d'autres conducteurs. Les formes les moins fréquemment rapportées (moins de $3 \%$ chacune) étaient les menaces de violence physique ou les agressions physiques. Les conducteurs de rickshaw moins expérimentés (moins de 10 ans de conduite) étaient davantage victimes de rage routière que les conducteurs pratiquant le métier depuis plus de dix ans $(P<0,01)$. Des études représentatives au niveau national sont nécessaires pour évaluer ce phénomène chez les conducteurs de véhicules utilitaires au Pakistan afin d'améliorer la sécurité routière.

'Independent Consultant, Al Rehab, Cairo, Egypt (Correspondence to M.A. Shaikh: masoodali1@yahoo.com).

${ }^{2}$ Emergency and Humanitarian Action Unit, World Health Organization Regional Office for the Eastern Mediterranean, Cairo, Egypt.

${ }^{3}$ Public Health Physician, Cantt, Rawalpindi, Pakistan.

Received: 01/01/09; accepted: 05/01/10 


\section{Introduction}

Road rage entails verbal abuse/threats or actual acts of physical harm by either a driver or passenger of one vehicle directed against the occupants of another vehicle or pedestrians, and could potentially lead to injuries or death and economically burden its victims [1]. Road rage has been associated with psychiatric illnesses in both the perpetrators as well as the victims $[2,3]$. In a previous study in Islamabad, Pakistan, among a sample of 532 university students, 30\% reported they had experienced being shouted at, cursed or made rude gestures at while driving a vehicle in the past 3 months [4]. Another study in Pakistan reported that the most common type of road rage experienced by bus drivers was someone in another vehicle making rude gestures at them; this was reported by 156 (88.6\%) bus drivers in Islamabad and Rawalpindi [5].

A rickshaw is a three-wheeler motor vehicle and is a common mode of transport for hire in Pakistan. This study was conducted to gain insight into road rage experiences and behaviours of rickshaw drivers and the association with years of having driven rickshaw in the city of Rawalpindi.

\section{Methods}

A cross-sectional survey with convenience sampling was conducted among rickshaw drivers in Rawalpindiat various frequently visited city areas and popular destinations from January to May 2008. An interviewer-administered, pre-tested, structured questionnaire with close-ended questions was used. Rickshaw drivers who had been driving for at least 1 year were interviewed by a trained interviewer, after giving verbal consent.

Results were analysed using STATA, version 9. The chi-squared and Fisher exact tests were used to test the difference between the drivers' experience and behaviour regarding road rage by length of time they had been driving a rickshaw $(\leq 10$ years versus > 10 years).

\section{Results}

A total of 318 male drivers were approached and 303 agreed to be interviewed, a response rate of $95.3 \%$. The mean age of the rickshaw drivers was 38.7 years (range 20-55 years). On average, rickshaw drivers had been driving a rickshaw for 10.6 years (range $1-30$ years). Educational status was described by respondents as: 42 (13.9\%) with no formal education, 126 (41.6\%) with 2-5 years of education, and 135 (44.5\%) with 6-11 years of education. Smoking cigarettes on a regular basis was reported by $252(83.2 \%)$ of the respondents. Table 1 shows the frequency of road rage behaviour and experiences of rickshaw drivers in the past 3 months. The majority of drivers had both been shouted at and experienced rude gestures from other drivers (78.9\% for both), while fewer drivers said they had behaved the same themselves towards other drivers (55.8\% for shouting and cursing and $46.9 \%$ for making rude gestures). Threatening physical hurt or actually physically hurt was rare wither for rickshaw drivers or other drivers. Table 2 shows the association between road rage experiences/behaviours and length of time of rickshaw driving. Rickshaw drivers with shorter driving time ( $\leq 10$ years) had significantly more road rage experiences than those who had been driving for more than 10 years $(P$ $<0.01)$.

\section{Discussion}

The most common types of road rage experiences reported were being shouted/cursed at and having someone in another vehicle make rude gestures ( $78.9 \%$ of respondents), while fewer admitted to having either shouted or cursed at someone in another vehicle (55.8\%) or made of rude gestures at someone in another vehicle (46.9\%). Being either threatened with physical violence or having physically threatened someone in another vehicle was rare but nonetheless was reported by some respondents $(<3 \%)$.

Table 1 Road rage behaviour and experiences of rickshaw drivers, Rawalpindi, Pakistan

\begin{tabular}{lc}
\hline Behaviour/experience & $\begin{array}{c}\text { No. (\%) } \\
(\boldsymbol{n}=\mathbf{3 0 3})\end{array}$ \\
$\begin{array}{l}\text { In the past } 3 \text { months while I was driving: } \\
\text { Someone in another vehicle shouted or cursed at me } \\
\text { I shouted or cursed at someone in another vehicle }\end{array}$ & $239(78.9)$ \\
$\begin{array}{l}\text { Someone in another vehicle made rude gestures at me } \\
\text { I made rude gestures at someone in another vehicle }\end{array}$ & $239(78.9)$ \\
$\begin{array}{l}\text { Someone in another vehicle threatened to physically } \\
\text { hurt me }\end{array}$ & $142(46.9)$ \\
$\begin{array}{l}\text { I threatened to physically hurt someone in another vehicle } \\
\text { Someone in another vehicle threatened to damage my } \\
\text { vehicle } \\
\text { I threatened to damage someone's vehicle }\end{array}$ & $9(3.0)$ \\
$\begin{array}{l}\text { Someone in another vehicle damaged my vehicle or hurt } \\
\text { someone in my vehicle }\end{array}$ & $6(2.0)$ \\
$\begin{array}{l}\text { I damaged someone's vehicle or hurt some in another } \\
\text { vehicle }\end{array}$ & $35(12.2)$ \\
\hline
\end{tabular}




\begin{tabular}{|c|c|c|c|}
\hline \multirow[t]{2}{*}{ Behavior/experience $^{a}$} & \multicolumn{2}{|c|}{ Driven a rickshaw for: } & \multirow[t]{2}{*}{$P$-value } \\
\hline & $\leq 10$ years $(n=178)$ & $>10$ years $(n=125)$ & \\
\hline \multicolumn{4}{|c|}{ In the past three months while I was driving: } \\
\hline \multicolumn{4}{|c|}{ Someone in another vehicle shouted or cursed at me } \\
\hline Yes & 164 & 75 & $<0.001$ \\
\hline No & 14 & 50 & \\
\hline \multicolumn{4}{|c|}{ I shouted or cursed at someone in another vehicle } \\
\hline Yes & 133 & 36 & $<0.001$ \\
\hline No & 45 & 89 & \\
\hline \multicolumn{4}{|c|}{ Someone in another vehicle made rude gestures at me } \\
\hline Yes & 151 & 88 & 0.002 \\
\hline No & 27 & 37 & \\
\hline \multicolumn{4}{|c|}{ I made rude gestures at someone in another vehicle } \\
\hline Yes & 112 & 30 & $<0.001$ \\
\hline No & 66 & 95 & \\
\hline \multicolumn{4}{|c|}{ Someone in another vehicle threatened to damage my vehicle } \\
\hline Yes & 34 & 3 & $<0.001^{\mathrm{b}}$ \\
\hline No & 144 & 122 & \\
\hline \multicolumn{4}{|c|}{ I threatened to damage someone's vehicle } \\
\hline Yes & 32 & 3 & $<0.001^{\mathrm{b}}$ \\
\hline No & 146 & 122 & \\
\hline
\end{tabular}

${ }^{a}$ Only statistically significant associations are reported.

${ }^{b}$ The Fisher exact test was used because of values $<5$ in some categories.

The P-values apply to pair-wise comparison between 2 groups based on years of having driven a rickshaw.

Rickshaw drives who had driven for 10 years or less were more likely to have been offensive and also experienced the rage of others compared with drivers who had driven for more than 10 years. Perhaps having more than 10 years of rickshaw driving experience bestowed better skills to navigate roads and highways and to avoid provoking adverse reactions or anger of the drivers of other vehicles or their occupants. Alternatively, younger men could have been speedier and more aggressive drivers and hence got involved in more such incidents. Future studies on road rage need to address these questions.
The 2 previous studies conducted in Pakistan in conjunction with the results of this study suggest that verbal expression of road rage is a fairly common phenomenon. There is a need for larger, nationally representative surveys to study road age in commercial vehicle drivers so as to improve road safety in Pakistan.

\section{References}

1. Smart RG, Mann RE. Deaths and injuries from road rage: cases in Canadian newspapers. Canadian Medical Association Journal, 2002, 167:761-762.

2. Butters JE, Mann RE, Smart RG. Assessing road rage victimization and perpetration in the Ontario adult population: the impact of illicit drug use and psychiatric distress. Canadian Journal of Public Health, 2006, 97:96-99.

3. Fong G, Frost D, Stansfeld S. Road rage: a psychiatric phenomenon? Social Psychiatry and Psychiatric Epidemiology, 2001, 36:277-286.
4. Shaikh IA et al. Road rage behavior: Experiences of university students. Journal of the College of Physicians and Surgeons - Pakistan, 2005, 15:830-831.

5. Shaikh IA, Shaikh MA, Siddiqui Z. Road rage behavior and experiences of bus and wagon drivers in Islamabad and Rawalpindi. Journal of the Pakistan Medical Association, 2008, 58(4):220-221. 